\title{
FATHOM
}

\section{'Paint, not the thing, but the effect it produces': The Power of Impressions in Far from the Madding crowd}

'Paint, not the thing, but the effect it produces' : le pouvoir des impressions dans Far from the Madding Crowd

\section{Thierry Goater}

\section{OpenEdition}

\section{Journals}

\section{Electronic version}

URL: http://journals.openedition.org/fathom/492

DOI: $10.4000 /$ fathom.492

ISSN: 2270-6798

\section{Publisher}

Association française sur les études sur Thomas Hardy

\section{Electronic reference}

Thierry Goater, «'Paint, not the thing, but the effect it produces': The Power of Impressions in Far from the Madding Crowd », FATHOM [Online], 3 | 2016, Online since 30 April 2016, connection on 01 May 2019. URL : http://journals.openedition.org/fathom/492 ; DOI : 10.4000/fathom.492 


\title{
'Paint, not the thing, but the effect it produces': The Power of Impressions in Far from the Madding Crowd
}

\author{
'Paint, not the thing, but the effect it produces' : le pouvoir des impressions \\ dans Far from the Madding Crowd
}

Thierry Goater

1 The quotation in the title of this paper comes from a letter Stéphane Mallarmé wrote to Henri Cazalis in 1864 (cited in Jones 510). The definition the French poet gives of his technique sounds quite close to Hardy's conception of fictional representation. In July 1892 Hardy wrote: "We don't always remember as we should that in getting at the truth, we only get at the true nature of the impression that an object, etc., produces on us, the true thing in itself being still, as Kant shows, beyond our knowledge" (F. Hardy 9, my emphasis).

2 According to Hardy, the artist cannot represent the truth, a truth which is impossible to get at, but only an impression, the effect produced by the object on the subject. Indeed, for Hardy, art is above all a matter of impression, one of the key terms that define his aesthetics. The writer constantly uses it to comment upon his novelistic or poetic art, be it in his personal writings, in his autobiography or in the prefaces to his works. Hardy was very much influenced by $18^{\text {th }}$ - and $19^{\text {th }}$-century scientific and philosophical writings on the theory of perception, on the role played by subjectivity, by emotions in perception and understanding. In Hardy's fictions and in Far from the Madding Crowd in particular "impression" should be understood in a broad sense. Following the definitions of the Oxford English Dictionary, at a concrete level, "impression" refers to "a mark produced on a surface by pressure, specially by the application of a stamp, seal, etc.", "the process or result of printing"; at an abstract level, it is "an effect produced on the mind, conscience, or feelings", "an effect produced on the senses, a sensation", or "a (vague or mistaken) 
notion or belief impressed on the mind". In this paper I wish to highlight the central role and the ambiguous power of impressions in Far from the Madding Crowd, underlining the relations between the diegetic and extradiegetic levels, the possible parallels between character, narrator/author and reader, and drawing attention to the impact on representation and reception. The first two sections will consider how reality is apprehended by visual impressions in the novel, emphasizing the subjective nature of the vision of the characters, who are likely to be misled, and of the author, who attempts to attain a hidden truth. The next two sections will focus on the paradoxical effects produced on the reader. I will attempt to show how Hardy's writing aims to make an impression on the reader and conversely how the novelist's impressions challenge that same reader and foreshadow a crisis of fictional representation.

\section{The subjectivity of vision}

Hume's A Treatise of Human Nature, Berkeley's Essay Towards a New Theory of Vision and especially the Berkeleian idea that "esse is percepi" had a strong impact on Hardy (Bullen 80-81). External reality is the one we perceive, the impression it produces on our senses. Hardy was also deeply influenced by the scientific and philosophical thought of the middle of the $19^{\text {th }}$ century. Herbert Spencer - especially in his Principles of Psychology and Auguste Comte imperilled the credo of absolute objectivity by stressing the role of biology and of emotions in our perceptions. When Tess sees in nature signs of reprobation about what took place in the Chase, the narrator makes the well-known comment: "The world is only a psychological phenomenon" (Hardy 1985a, 134). Affects are highly significant in our vision of the world. In Far from the Madding Crowd Hardy already states the importance of subjective vision clearly, for example when Gabriel Oak is watching Bathsheba through a crevice in the roof of the shed and must content himself with imagining her features because of the hood she is wearing.

Oak, upon hearing these remarks, became more curious to observe her features, but his prospect being denied him by the hooding effect of the cloak, and by his aërial position, he felt himself drawing upon his fancy for their details. In making even horizontal and clear inspections we colour and mould according to the wants within us whatever our eyes bring in. 覧...熙 Having for some time known the want of a satisfactory form to fill an increasing void within him, his position moreover affording the widest scope for his fancy, he painted her a beauty (Hardy 1986, 16-17).

Were Oak to see Bathsheba's face clearly, he would still impress his emotions and his desires on her features, as is clearly pointed out by the narrator. But his limited vision increases his subjectivity, the part played by his desires ("curious", "want", "void") and imagination ("fancy"). The character's impression is like a "painted" portrait, a transfiguration of reality. Throughout the novel impressions keep playing an important role in the characters' lives, misleading them, inducing them to take wrong actions. In Bathsheba's eyes the world appears quite differently after meeting Troy, dazzled as she is by his dashing personality and his military prowess:

In an instant the atmosphere was transformed to Bathsheba's eyes. Beams of light caught from the low sun's rays, above, around, in front of her, well-nigh shut out earth and heaven - all emitted in the marvellous evolutions of Troy's reflecting blade, which seemed everywhere at once, and yet nowhere specially. These circling gleams were accompanied by a keen rush that was almost a whistling - also springing from all sides of her at once. In short, she was enclosed in a firmament of light, and of sharp 
hisses, resembling a sky-full of meteors close at hand. (Hardy 1986, 144, my emphasis) perception of herself and the others, Boldwood's perception remains problematic, for it is hindered by too strong emotions he cannot control. Hardy's awareness of the importance of the subjectivity of vision is strikingly translated in the novel through a major innovation in the narrative technique and more particularly in the handling of point of view. While in his first three fictions - Desperate Remedies, Under the Greenwood Tree and A Pair of Blue Eyes - focalization is mainly external, the narrator observing events and characters from outside, in Far from the Madding Crowd internal focalization takes a much greater place (Bullen 68). The reality represented in the novel is as much the one filtered through the characters' eyes as the one perceived by the narrator. The novelist presents the reader with his characters' impressions, with their eminently subjective vision of reality, with their regard influenced by their idiosyncrasies. But adopting internal focalization can hardly be a sufficient device. The subjectivity of vision implies another mode of writing, another mode of regard for the writer himself.

\section{"The author's idiosyncratic mode of regard"}

After reading Ruskin, especially his Modern Painters in the early 1860s, Hardy immediately understood the artistic importance of the contribution of scientific and philosophical thought and while starting to write fiction he began to elaborate a theory based on perception (Bullen 63). The basis, the driving force of Hardy's writing is vision, impression.

In this respect, the title of chapter XIV in Far from the Madding Crowd becomes most revealing: "The effect of the Letter - Sunrise". Obviously it draws attention to the effect the object has on the subject, to the impression the letter has on Boldwood. The title, however, is surprisingly reminiscent of Impression, Sunrise, the painting by Monet that opened up the way for Impressionism. And the sunrise watched by Boldwood in the morning following the reception of the Valentine bears some resemblance to Monet's work, even if Hardy compares the sunrise seen by the farmer to a sunset at the end of the excerpt:

Then the dawn drew on. The full power of the clear heaven was not equal to that of a cloudy sky at noon, when Boldwood arose and dressed himself. He descended the stairs and went out towards the gate of a field to the east, leaning over which he paused and looked around.

FATHOM, 3 | 2016 
It was one of the usual slow sunrises of this time of the year, and the sky, pure violet in the zenith, was leaden to the northward, and murky to the east, where, over the snowy down or ewe-lease on Weatherbury Upper Farm, and apparently resting upon the ridge, the only half of the sun yet visible burnt rayless, like a red and flameless fire shining over a white hearthstone. The whole effect resembled a sunset as childhood resembles age. (Hardy 1986, 81, my emphasis)

Hardy became aware of a possible relation between his art and the French school of painting, at least concerning the paramount importance of subjective vision. After visiting an exhibition at the Society of British Artists he wrote a note dated December 7, 1886:

The Impressionist school is strong. It is even more suggestive in the direction of literature than in that of art. As usual it is pushed to absurdity by some. But their principle is, as I understand it, that what you carry away with you from a scene is the true feature to grasp; or in other words, what appeals to your own individual eye and heart in particular amid much that does not so appeal, and which you therefore omit to record. (F. Hardy 261)

The artist's role consists in "grasping" the sensation left by an object, by a scene on the "individual eye and heart". The writer must convey his characters' subjective vision through his own personal vision, as Hardy wrote in a note of March-April 1890: "Art consists in so depicting the common events of life as to bring out the features which illustrate the author's idiosyncratic mode of regard; making old incidents and things seem as new" (F. Hardy 294). Hardy represents the "common events of life" and even more so psychological states or dramatic situations by way of visualizations characteristic of his subjectivity and imagination. Hardy's impressions make extensive use of imagery, of intensification (231-232) ${ }^{1}$ and distortion, a method opposed to mimetic realism. In August 8, 1890, he wrote:

Art is a disproportioning - (i.e. distorting, throwing out of proportion) - of realities, to show more clearly the features that matter in those realities, which, if merely copied or reported inventorially, might possibly be observed, but would more probably be overlooked. Hence 'realism' is not Art. (299) ${ }^{2}$

Like most of Hardy's novels, Far from the Madding Crowd provides many descriptions or scenes relying on intensification and distortion. The episode when Oak watches his environment after the tragic loss of his sheep is perfect evidence of this:

Oak raised his head, and wondering what he could do, listlessly surveyed the scene. By the outer margin of the pit was an oval pond, and over it hung the attenuated skeleton of a chrome-yellow moon, which had only a few days to last -the morning star dogging her on her left hand. The pool glittered like a dead man's eye, and as the world awoke a breeze blew, shaking and elongating the reflection of the moon without breaking it, and turning the image of the star to a phosphoric streak upon the water. All this Oak saw and remembered. (Hardy 1986, 33, my emphasis)

The description is bracketed by verbs indicating the character's focalization, the subjectivity of his vision. The forceful metaphor and simile to depict the moon and the pool conjure up a weird and worrying atmosphere akin to Unheimlichkeit. Functioning like a memento mori, they convey the vanity of life and Oak's despair. The description of the landscape is imbued with the character's sensibility, with his dejection, like Turner's watercolours which Hardy saw at the Royal Academy in London in 1871: "Turner's watercolours: each is a landscape plus a man's soul." (F. Hardy, 283, original emphasis) 

only be apprehended by a style akin to "the much decried, mad, late-Turner" (January 1887; F. Hardy 243). What may sound paradoxical is not for Hardy. It is the distortion of reality, the "illusion of truth" that allows the artist to be actually "more truthful than truth" (Hardy, "The Science of Fiction, in Orel 134-135). Purely mimetic representation cannot go beyond mere description, whereas Hardy wished to "see the deeper reality underlying the scenic" (January 1887; F. Hardy 242). To probe into the mysteries of life and notably the pathos of humanity, the artist cannot content himself with mimetic description, with the "outer senses":

A sight for the finer qualities of existence, an ear for the "still sad music of humanity", are not to be acquired by the outer senses alone, close as their powers in photography may be. What cannot be discerned by eye and ear, what may be apprehended only by the mental tactility that comes from a sympathetic appreciativeness of life in all of its manifestations, this is the gift which renders its possessor a more accurate delineator of human nature than many another with twice his powers and means of external observation, but without that sympathy. (Hardy, "The Science of Fiction", in Orel 137) 3

Grotesque or melodramatic distortions give Hardy the power to convey the "still sad music of humanity", to represent Oak's despair, the effect of the Valentine on Boldwood, the impression Troy makes on Bathsheba and the scenes involving Fanny Robin. They reveal Hardy's sympathetic regard, his "power of observation informed by a living heart." (Orel 138)

18 "Realities, [...] if merely copied or reported inventorially, might possibly be observed, but would more probably be overlooked", Hardy states, as mentioned above (F. Hardy 299). Another aim of Hardy's is indeed to produce an effect, to make an impression on his reader, to leave a mark on his mind and sensibility. 


\section{The Ancient Mariner and the Wedding Guest}

19 To all those who blamed him for enslaving himself to the demands of his editors and the reading public by yielding to sensationalism, Hardy replied that he wished to be "a good hand at a serial" (Letter to L. Stephen, Hardy 1986, 343), a story-teller whose narratives could arouse the reader's interest. In February 1893 he wrote:

A story must be exceptional enough to justify its telling. We tale-tellers are all Ancient Mariners, and none of us is warranted in stopping Wedding Guests (in other words, the hurrying public) unless he has something more unusual to relate than the ordinary experience of every average man and woman (F. Hardy 15-16).

Hardy shows a keen interest in a form of praxis of reading. He is extremely conscious of the inter-subjective relation established between text, narration and the receiving conscience. His narrators must be like the Ancient Mariner in Coleridge's famous Rime, who fascinates the Wedding Guest with his narrative. They must produce on the reader an effect approaching the one produced on Oak by the landscape. The effect of the text requires a story which must be "exceptional", "unusual", which goes beyond ordinary experience through an aesthetic totally different from mimetic realism. The art of disproportion claimed by Hardy favours an essential aspect of aesthetic experience, aisthesis, which allows the artist to renew a perception dulled by habit (Jauss 144) ${ }^{4}$. The melodramatic sensationalism of many episodes in Far from the Madding Crowd, like the scene in which Bathsheba and Troy stand by Fanny's coffin or the one in which Boldwood shoots Troy dead, should be interpreted in this manner. Likewise, the visual distortions contribute to impressing the reader. The purpose is to create surprise, to affect, to touch the reader by striking his imagination through descriptions relying on vivid imagery. A good illustration is provided by the famous storm episode:

Heaven opened then, indeed. The flash was almost too novel for its inexpressibly dangerous nature to be at once realized, and they could only comprehend the magnificence of its beauty. It sprang from east, west, north, south, and was a perfect dance of death. The forms of skeletons appeared in the air, shaped with blue fire for bones - dancing, leaping, striding, racing around, and mingling altogether in unparalleled confusion. (Hardy 1986, 193-194)

Presenting the storm like a "dance of death", Hardy tries to convey a spectacle of an incredible and terrifying beauty, one that is almost impossible to express ("inexpressibly") or to understand ("could only comprehend") because it is new, extraordinary ("novel", "unparalleled"). Of course, the pronoun "they" refers to the characters but might just as well be applied to the readers. Hardy's purpose is to strike the latter's conscience in the same way as Gabriel's and Bathsheba's conscience is struck by the storm. This can only be achieved by forceful visualizations, by a manner drawing upon the sublime or the grotesque and not upon mimetic realism. Virginia Woolf was one of the first to grasp the full value of Hardy's impressions in Far from the Madding Crowd:

His own word, "moments of vision", exactly describes those passages of astonishing beauty and force which are to be found in every book that he wrote. With a sudden quickening of power which we cannot foretell, nor he, it seems, control, a single scene breaks off from the rest. We see, as if it existed alone and for all time, the wagon with Fanny's dead body inside travelling along the road under the dripping trees; we see the bloated sheep struggling among the clover; we see Troy flashing his sword round Bathsheba where she stands motionless, cutting the lock off her head and spitting the caterpillar on her breast. Vivid not to the eye alone, for every 
sense participates, such scenes dawn upon us and their splendour remains. (Woolf

247-248)

Woolf aptly underlines the "astonishing beauty and force" of such scenes, their ability to remain imprinted on our memory ("such scenes dawn upon us and their splendour remains"). The reader finds himself in the same position as Oak watching the scene of despair after the loss of his sheep ("All this Oak saw and remembered") and will remember the scenes he read. Woolf also evokes the effect of Hardy's "moments of vision" on all our senses ("vivid not to the eye alone, for every sense participates"). Indeed the Hardyesque impressions strike the reader's sensibility; they appeal to his emotions.

Many scenes arouse awe, pity and admiration in the reader in a relation of identification with the characters. Melodrama may allow the novelist to comply with the demands of his readership but it also allows him to produce an aesthetic and cathartic effect with a possible real ideological impact. Melodrama is usually regarded as a highly conventional genre, one that enforces norms. However, it may also subvert those norms. The empathetic episode presenting Fanny early in the novel, when Gabriel's fingers feel the "throb of tragic intensity" on her wrist (Hardy 1986, 44), and the empathetic scenes showing her painful walk towards the Union House where she will die and the journey of her dead body at night arouse the reader's pity and compassion. But one may also wonder to what extent they do not ironically induce the bourgeois Victorian reader to side with a 'fallen woman', a figure of exclusion. Hardy was well aware of the central role played by emotion in writing and in the reception of the artistic work: "It is the force of an appeal to the emotional reason rather than to the logical reason; for by their emotions men are acted upon and act upon others" (Hardy, "The Profitable Reading of Fiction" in Orel 115). Through the emotions that they arouse and play upon, Hardy's impressions favour the sympathetic communication stressed by Jauss as regards aesthetic experience, which then can result in symbolic action or action oriented towards solidarity (Jauss 164).

Hardy's impressions have the power to express hidden truths, to impress and act upon the reader. Yet, paradoxically, they can also challenge him and contribute to drawing attention to the frailty of representation.

\section{The broken mirror of representation}

25 Very far removed from the unity and transparency demanded by James or Flaubert, Hardy's writing seems to shed light on the limits of representative discourse by revealing or reflecting its inconsistencies and workings to the point of breaking fictional illusion. In the Preface to Jude the Obscure, Hardy humbly presents his novelistic project:

Like former productions of this pen, Jude the Obscure is simply an endeavour to give shape and coherence to a series of seemings, or personal impressions, the questions of their consistency or their discordance, of their permanence or their transitoriness, being regarded as not of the first moment (Hardy 1985b, 39-40).

Actually, in Far from the Madding Crowd the coherence of impressions is somewhat imperilled by modal "discordance". Realist representation, expressionist aesthetics and Gothic melodrama, are sometimes incongruously juxtaposed. Antirealist scenes seem to break off from the realist frame. Discordance may also result from the multiplicity of impressions, from the multiplicity of subjective points of view. The character of Bathsheba, for instance, generates a series of portraits, which constitute different and 
sometimes contradictory viewpoints on the young woman. Thus the unifying power of narration is likely to be jeopardized, all the more so as, although the omniscient narrator's voice can be heard, often very sonorously, it betrays its uncertainties as well. The narrator cannot always provide more than his characters' "conjectures" (Hardy 1986, 10 ), as in the passage in which Oak spies on Bathsheba's horse-riding performance:

The adjustment of the farmer's hazy conceptions of her charms to the portrait of herself she now presented him with was less a diminutive than a difference. The starting-point selected by the judgement was her height. She seemed tall, but her pail was a small one, and the hedge diminutive; hence, making allowance for error by comparison with these, she could have been not above the height to be chosen by women at best. All features of consequence were severe and regular. It may have been observed by persons who go about the shires with eyes for beauty that in Englishwomen a classically-formed face is seldom found to be united with a figure of the same pattern 臨...監. From the contours of her figure in its upper part she must have had a beautiful neck and shoulders; but since her infancy nobody had even seen them. (Hardy 1986, 18-19)

The extract mainly provides Oak's point of view. The adjective "hazy", the verb "seemed", as well as the epistemic modals "could" and "must", convey the uncertainties of the impressions of an observer whose perception is limited, dependent on the possibility of "error" and on the laws of perspective ("She seemed tall, but her pail was a small one, and the hedge diminutive"). The omniscient narrator does step in through a general comment ("It may have been observed...") and he broadens the temporal framework ("since her infancy") but refrains from doing so at the visual level ("nobody had even seen them").

Language itself shows its powerlessness: "He wished she knew his impressions; but he would as soon have thought of carrying an odour in a net as of attempting to convey the intangibilities of his feeling in the coarse meshes of language. So he remained silent." ( Hardy 1986, 21) One can read in the narrator's words about Oak a metatextual comment on writing. For Hardy, language, ordinary language, is a "coarse" instrument, unable to convey "impressions". Only metaphoric language can express intangible impressions. And in the same passage the narrator expresses himself by way of an extended metaphor ("carrying an odour in a net", "coarse meshes of language"). Hardy's writing often becomes metaphoric, visual, or poetic, for mimetic discourse leads to silence, to Oak's silence or Hardy's fictional silence after the publication of Jude the Obscure.

Hardy's writing foregrounds itself, the text displaying its artistic status and its semiotic nature. As Virginia Woolf herself felt, the memorable scenes seem to "break off from the rest". Needless to say purple patches are frequently found in novels. The artistic exemplum exhibits the artist's work transfiguring the real, transforming it into a picture. Hardy, however, makes excessive use of the device and overexposes it, as it were. The technique of focalization in itself results in framing. For example, the reader is presented with a view inside the shearing barn:

To-day the large side doors were thrown open towards the sun to admit a bountiful light to the immediate spot of the shearers' operations, which was the wood threshing-floor in the centre, formed of thick oak, black with age and polished by the beating of flails for many generations, till it had grown as slippery and as rich in

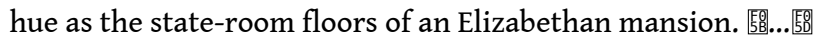

This picture of to-day in its frame of four hundred years ago did not produce that marked contrast between ancient and modern which is implied by the contrast of date. (Hardy 1986, 114, my emphasis) 
narrator-focalizer draws the curtain ("To-day the large side doors were thrown open"), sets up the décor with light effects. The terrifying description of the revel scene in the barn before the storm is seen through Oak's eyes and is similarly introduced: "Gabriel looked in. An unusual picture met his eye." (Hardy 1986, 189, my emphasis) In both examples the word "picture" highlights the process. As for characters, they are presented as figures within pictures or even as pictorial realities. The very first paragraph of the novel introduces Oak:

When Farmer Oak smiled, the corners of his mouth spread till they were within an unimportant distance of his ears, his eyes were reduced to chinks, and diverging wrinkles appeared round them, extending upon his countenance like the rays in a rudimentary sketch of the rising sun. (7, my emphasis)

A portrait of Liddy is also drawn in a pictorial fashion:

The beauty her features might have lacked in form was amply made up for by perfection of hue, which at this winter-time was the softened ruddiness on a surface of high rotundity that we meet with in a Terburg or Gerard Douw; and, like the presentations of those great colourists, it was a face which kept well back from the boundary between comeliness and the ideal. (60, my emphasis)

In both portraits anatomic order is turned into pictorial order: human features are compared to signs on a sketch or a painting. Hardy's impressions often move towards pictorial semiotization. During the "pastoral tragedy" the faded slate-grey of the hair of Oak's older dog is "like the indigo from the same kind of colour in Turner's pictures" (31). When Oak reprimands Bathsheba, her face colours "with the angry crimson of a Danby sunset" (105). When the rain and the gargoyle have stopped pouring on Fanny's grave, the sunshine through the leaves has a "brightness of similar effects in the landscapes of Ruysdael and Hobbema." (242) As for the light effects inside the tent at Greenhill fair, they are thus presented: "The strange luminous semi-opacities of fine autumn afternoons and eves intensified into Rembrandt effects the few yellow sunbeams

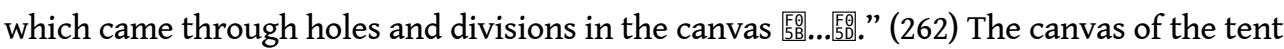
is assimilated to the canvas of a painting of the Dutch master of chiaroscuro. All these examples show how Hardy displays the artistic status of his settings and characters. They have no other reality than that of the pictorial signs the writer uses to represent them. Then the descriptions are just artefacts like the works by the numerous painters mentioned in the text.

In Far from the Madding Crowd the text is liable to become iconic, made up of pictorial impressions as it is. It often turns into a fetish, too. Like the allusions to painters, the numerous references to great literary authors (Virgil, Shakespeare, Milton, Shelley, Keats, Browning, etc.) are evidence of the author's culture and therefore may reinforce narrative reliability. On the other hand, they contribute to stressing the status of Hardy's novel, a literary work among other literary works. Furthermore, some written text is printed within the novel. The Hardyesque impressions then have another meaning, one that is related to printing. Far from the Madding Crowd turns into a corpus of texts, a patchwork of countless quotations. The quotations can be inserted in the text like the one from Shelley's "Ode to the West Wind": "Bathsheba shook her dress to get rid of them, when multitudes of the same family lying round about her rose and fluttered away in the breeze thus created, 'like ghosts from an enchanter fleeing."' (Hardy 1986, 232, my emphasis) They can also be set into relief in autonomous paragraphs like the quotation from Macbeth:

- Full of sound and fury 
- Signifying nothing- (Hardy 1986, 24) the diegetic level, impressions are misleading and challenge the characters' hermeneutic skills. At the narrative level, the effect produced by Hardy's impressions proves rather ambiguous. On the one hand, impressions allow the artist to represent the subjectivity of vision, to grasp hidden truths, to express the inexpressible by means of intensification and distortion. They also allow the writer to act upon the reader: the novel provides forceful scenes, which produce a long-lasting effect on the reader's mind and sensibility. On the other hand, Hardy's impressions may undermine representation itself by drawing attention to its cogs and wheels, so to speak. The repeated foregrounding of the processes of representation runs the risk of breaking fictional illusion. Far from the Madding Crowd prefigures a crisis of representation, which cannot be pure mimesis insofar as it is first and foremost semiosis. Through constant pictorial and textual impressions embedded in the narrative, representation eventually results in artifice and stasis because as such it tells death, it is death, as Derrida claims (Derrida 335). The alienating foregrounding of representative discourse is carried on in Hardy's following novels and reaches a climax in Jude the Obscure (see Goater 319-342) that marks the end of the author's novelistic career and his return to poetic writing, possibly more capable of expressing his impressions, his "moments of vision".

\section{BIBLIOGRAPHY}

Bullen, J. B., The Expressive Eye: Fiction and Perception in the Work of Thomas Hardy, Oxford:

Clarendon Press, 1986.

Derrida, Jacques, L'écriture et la difference (1967), Paris: Seuil, 1979.

FATHOM, 3 | 2016 
Eells, Emily, “'The Noiseless Tenor of their Way': Quotations, Inscriptions and the Words of Others in Far from the Madding Crowd", Thomas Hardy: Far from the Madding Crowd, eds. Annie Ramel \& Christian Gutleben, Cycnos 26.2, Paris: L'Harmattan, 2010, 137-148.

Genette, Gérard, Figures II (1969), Paris: Seuil, 1979.

Gilmour, Robin, The Novel in the Victorian Age: A Modern Introduction, London: Edward Arnold, 1986.

Goater, Thierry, Thomas Hardy: Figures de l'aliénation, Rennes: Presses Universitaires de Rennes, 2010.

Hardy, Florence, The Life of Thomas Hardy (1930), London: Studio Editions, 1994.

Hardy, Thomas, Tess of the d'Urbervilles (1891), ed. David Skilton, Harmondsworth: Penguin, 1985.

Hardy, Thomas, Jude the Obscure (1895), ed. C. H. Sisson, Harmondsworth: Penguin Classics, 1985.

Hardy, Thomas, Far from the Madding Crowd (1874), ed. Robert C. Schweik, New York \& London: Norton, 1986.

Jauss, H. R., Pour une esthétique de la réception (1972-1975), transl. Claude Maillard, Paris: Gallimard, 1998.

Jones, Lawrence O., "Imitation and Expression in Thomas Hardy's Theory of Fiction", Studies in the Novel 7 (1975): 507-525.

Orel, Harold (ed.), Thomas Hardy's Personal Writings (1966), London: Macmillan, 1990.

Woolf, Virginia, “The Novels of Thomas Hardy" (1928), The Common Reader, vol. II (1932), London: The Hogarth Press, 1986, 245-257.

\section{NOTES}

1. "My art is to intensify the expression of things, as is done by Crivelli, Bellini, etc. so that the heart and inner meaning is made vividly visible." (January 3, 1886; F. Hardy 231-232).

2. Throughout the Victorian era, fiction gave rise to a debate between realism and antirealism. The debate was revived with the rise of French naturalism and the return of romance with Stevenson (Gilmour 180). However, as soon as he started writing fiction and before the debate over realism was revived, Hardy rejected Zola's "roman expérimental" or scientific novel.

3. Orel reminds us that the phrase "still sad music of humanity" is a quotation from Wordsworth's "Lines Composed a Few Miles above Tintern Abbey, on Revisiting the Banks of the Wye during a Tour".

4. Jauss reminds us that the three key concepts of the aesthetic tradition are poiesis, aisthesis, and catharsis.

5. On the possible "contradiction between the written text and reality" and on the use of quotations and inscriptions in the novel, see Eells 144.

6. Hardy entitled his fifth collection of poems, published in 1917, Moments of Vision. 


\section{ABSTRACTS}

"Impression" is an eminently Hardyesque word which keeps occurring in the author's fictional texts as well as in his personal and theoretical writings. The term, which suffers from an extensive, almost inflationary use, is related to fields such as phenomenology, psychology, cognitive sciences, art theory or simply printing. The aim of this paper is to emphasize the importance and role of impressions in Far from the Madding Crowd, Hardy's first major novel, at both the diegetic and narrative levels. For Hardy, impressions are central in man's perception and interpretation of the world, hence characters whose understanding and actions are often heavily dependent on impressions. Impressions are also crucial in the writer's technique, in his aesthetics ; they partake of what Hardy himself calls "the author's idiosyncratic mode of regard". Impressions in Hardy's work raise important questions concerning reality, truth, the power and validity of fictional representation, and readers' response.

« Impression » est un mot éminemment hardyen, dont on trouve de très nombreuses occurrences dans les textes fictionnels de l'auteur, comme dans ses écrits personnels et théoriques. Ce terme, qui souffre d'un emploi extensif et presque inflationniste, se trouve au croisement de domaines aussi variés que la phénoménologie, la psychologie, les sciences cognitives, la théorie de l'art ou plus simplement l'imprimerie. Cet article a pour objet de souligner l'importance et la fonction des impressions dans Far from the Madding Crowd, premier roman majeur de Hardy, sur le plan diégétique comme sur le plan narratif. Pour Hardy, les impressions sont centrales dans la manière qu'a l'homme de percevoir le monde et de l'interpréter, d'où des personnages dont la compréhension et les actions en dépendent fortement. Les impressions sont également cruciales dans la technique, dans l'esthétique de l'écrivain; elles participent de ce que Hardy lui-même appelle « le mode de regard idiosyncratique de l'auteur ». Les impressions dans l'œuvre de Hardy soulèvent d'importantes questions concernant la réalité, la vérité, le pouvoir et la validité de la représentation fictionnelle ou encore la réception par les lecteurs.

\section{INDEX}

Mots-clés: représentation, réception, esthétique, expressionnisme, impressions, mimesis, semiosis, regard

Keywords: representation, reception, aesthetics, expressionism, impressions, mimesis, semiosis, gaze

\section{AUTHOR}

\section{THIERRY GOATER}

Thierry Goater is Senior Lecturer in the department of English at the University of Rennes 2. He wrote his doctoral dissertation (PhD thesis) on Thomas Hardy's "Novels of Character and Environment". He has published articles on Thomas Hardy, D.H. Lawrence and Jane Austen. His monograph Thomas Hardy - Figures de l'aliénation (Presses Universitaires de Rennes) was 
published in November 2010. He is currently co-editing a collection of articles on commitment in $18^{\text {th }}$ - and $19^{\text {th }}$-century British feminine novels to be published in 2012. 